\title{
PROBLEMS WITH THE IMPLEMENTATION OF BUS TRANSPORT CONTRACTING IN SOUTH AFRICA
}

\author{
JACKIE WALTERS* \\ GERT HEYNS** \\ *jwalters@uj.ac.za \\ Institute of Transport and Logistics Studies (Africa) \\ University of Johannesburg \\ South Africa \\ **gjheyns@uj.ac.za \\ Institute of Transport and Logistics Studies (Africa) \\ University of Johannesburg \\ South Africa
}

\begin{abstract}
South Africa has had a policy of competitive tendering for the provision of public transport services (subsidised commuter bus services) since the mid-1980s. Although this policy approach was conceptualised by the previous government, prior to the transfer of political power in 1994, it was reaffirmed in a 1996 White Paper on National Transport Policy. Despite the nearly 25 years that have passed since the intention to tender services, only about $32 \%$ of the subsidy budget is currently spent on some form of contracting. The majority of services are still operated on authorisations (interim contracts) which formalised services that operators were operating pre-1994. The purpose of this paper is to analyse the reasons why public transport contracting policy progress has been so slow in South Africa. The paper relies on an extensive study that was conducted regarding policy implementation obstacles in general, as well as a questionnaire survey among the subsidised commuter bus operators to solicit their views on the reasons for the delay in the implementation of the contracting system in the country. The findings of the survey indicate that the major issues hindering the implementation of the contracting system are to be found in a lack of funding, lack of capacity to implement policy and major operational issues in the permit offices.
\end{abstract}

\section{INTRODUCTION}

\section{South Africa's public transport policy in brief}

Public transport (PT) policy objectives in South Africa are mainly found in the White Paper on National Transport Policy of 1996 and ensuing legislation such as the National Land Transport Transition Act of 2000 (NLTTA) and the National Land Transport Act of 2009 that 
replaced the NLTTA. In later years a number of strategy documents were developed in support of the overall policy objective of improving public transport services in South Africa (Department of Transport, 2007a; Department of Transport, 2007b). The White Paper on National Transport Policy of 1996 (Department of Transport, 1996) however still remains valid, although now more than 15 years old, as the overall public transport policy objectives have not changed over this time.

The White Paper on National Transport Policy did not specifically make reference to commuter bus transport but dealt with it as part of the total passenger transport sector. The White Paper also envisaged the devolvement of effective and efficient planning, implementation, funding, regulation and law enforcement of the passenger transport system to the lowest competent level. The White Paper also states an objective of ensuring sustainable and dedicated funding for passenger transport.

Various other objectives for the bus sector were (quoted from Mitchell, 2009:201):

- 'Provide spatial reorientation to promote public transport over private cars

- Ensure economic viability of bus services requiring minimum financial support with improved access to work opportunities

- Address customer needs for safe, accessible, affordable and reliable bus transport services

- Implement a system of regulated competition based on passenger transport plans and tendered contracts

- Promote coordinated and integrated bus transport services'

Promote environmentally sensitive and energy-efficient bus transport services

Against this high level policy background the following section briefly highlights the progress that has been made with policy implementation in the subsidised commuter bus transport sector.

\section{Progress with the implementation of the public transport policy}

Following the 1996 White Paper, and as an interim measure to assist companies to 'get fit' and ready for the tendering system, the government concluded interim contracts with all subsidised operators in 1997. In essence, these contracts placed their existing services within the framework of a contract with all the rights and privileges associated with a contract of this nature. The intention was that these contracts would last up to three years before the operator's services were to be put out to tender; they were never intended to be long-term contracts.

Organised labour, however, objected to the competitive tendering regimen as it felt that labour would be prejudiced through lay-offs and a reduction in wages (through competitive pressure) and lack of continuity of employment as operators lost and gained services. 
This resulted in a tri-party Heads of Agreement $(\mathrm{HoA})^{1}$ between organised labour, the Department of Transport and the organised industry through its trade association the Southern African Bus Operators Association (SABOA). The agreement, among others, compelled any operator that obtained a competitively sourced tender to employ at least $75 \%$ of the required workforce from the incumbent operator, built in measures relating to retrenchment costs of those employees not offered jobs by the new operator; and made provision for a $10 \%$ right of first refusal that would give the incumbent operator a better chance to gain back its business in a competitive environment so as to provide for continuity of employment.

The tendering system began at a slow pace in 1997 and lasted until 2002 when government announced a moratorium on further tenders due to a lack of funds and the fact that integrated transport plans were not in place (a legislative requirement at the time - the Land Transport Transition Act of 2000 [NLTTA]) in terms of which services had to be put out to tender. During this period organised labour voiced their continued objection to the tendering system after it was determined that in some contracts labour lost between 37\% and $75 \%$ of their original wages when switching from one operator to another (Walters \& Cloete, 2001) as well as losing all accumulated benefits in the switching. The dispute about the HoA has, after nearly 12 years and about 50 engagement processes between the triparty role players, not been resolved and the country has not seen another competitively sourced subsidised public transport service since then.

The NLTTA, however, made provision for negotiated contracts under certain circumstances, for instance, to encourage previously disadvantaged individuals to participate in the system and majority black ownership within two years of commencement of the contract. Hensher and Stanley (2010) describes negotiation as the process 'through which parties perceive one or more incompatibilities between them, and work to find a mutually acceptable solution'. In South Africa, the parties to the negotiations involve the transport operator, organised labour and the relevant transport authority. In this regard, a number of negotiated contracts were concluded in the early 2000s. With these types of contracts the HoA are not applicable as the incumbent bus company's labour, its management and the responsible provincial authority jointly agree on the labour conditions within such a contract. In some cases this led to a moratorium on retrenchments for one year following the beginning of operations.

In 2009 a new National Land Transport Act (Department of Transport, 2009) was enacted which makes provision for both tendered and negotiated contracts, and strengthened the principle of negotiated contracts, e.g. that such a contract could follow a currently

\footnotetext{
${ }^{1}$ Due to the complexity of the transition between interim contracts and tendered contracts, especially the labour issues, the Department of Transport decided to formalise the transitional arrangements (between interim and tendered contracts) by means of an agreement between organised labour, the Southern African Bus Operators Association (SABOA), and the Department of Transport. This became the Tripartite Heads of Agreement (HoA) that guided the industry and the DoT on policy implementation. The HoA was signed in 1999.
} 
tendered service. This Act placed public transport matters firmly at the local authority level of government (metros and local municipalities) and also made provision for negotiated contracts with a duration of up to 12 years. Other competitively sourced contracts would be seven years in duration. Another principle embodied in the Act is that integrated transport plans need to be developed so that the various types of service providers (bus, rail and taxi) operate in an integrated and coordinated manner in delivering their services. The avoidance of the duplication of service delivery and subsidies is another objective of Integrated Transport Plans (ITPs).

The progress with the development of ITPs has been very slow, although most major metropolitan areas have made some progress. Nowhere in the country, to the best of the authors' knowledge, has any negotiation process with incumbent operators been put in place to discuss the drafting of such plans, or to discuss the principles embodied in the plans. In the smaller municipalities major problems are being experienced regarding the expertise to develop, implement, manage and monitor such plans.

In anticipation of contracts based on integrated transport plans, any contract that expires (most have by now) is renewed on a short-term month-to-month basis and in some circumstances on a three- and six-monthly basis. A summary of the various forms of contracting (tendered, ${ }^{2}$ negotiated ${ }^{3}$ and interim contracts ${ }^{4}$ ) is depicted in Table I. The differences in approach between tendered and negotiated contracts are summarised in Table II.

Table I: Contract systems in place in South Africa

\begin{tabular}{|c|c|c|c|}
\hline Type of contract & $\begin{array}{l}\text { Number of } \\
\text { buses }\end{array}$ & Contract characteristics & Duration \\
\hline Interim contracts & $\begin{array}{c} \pm 3849(68 \% \\
\text { of subsidy } \\
\text { budget) }\end{array}$ & $\begin{array}{l}\text { - Foreseen as transition } \\
\text { arrangement in } 1997\end{array}$ & $\begin{array}{l}\text { - } 1-3 \text { years originally } \\
\text { - In practice some interim } \\
\text { contracts are } 15 \text { years old }\end{array}$ \\
\hline Tendered contracts & $\begin{array}{c} \pm 1834(28 \% \\
\text { of subsidy } \\
\text { budget) }\end{array}$ & $\begin{array}{l}\text { - Based on standard contract } \\
\text { document } \\
\text { - Mostly 'standalone' services } \\
\text { in rural/urban operations }\end{array}$ & $\begin{array}{l}\text { - } 5 \text { years originally } \\
\text { - Contracts are being extended } \\
\text { to } 7 \text { years } \\
\text { - New contracts to be } 7 \text { years } \\
\text { - Most contracts are currently } \\
\text { on a month-to-month basis }\end{array}$ \\
\hline $\begin{array}{l}\text { Negotiated } \\
\text { contracts }\end{array}$ & 250 & $\begin{array}{l}\text { Mostly applicable to state- } \\
\text { owned and operated } \\
\text { bus companies (form of } \\
\text { privatisation) }\end{array}$ & $\begin{array}{l}\text { - } 5 \text { years originally } \\
\text { - New contracts to be } 7 \text { years. } \\
\text { - Some contracts on a month- } \\
\text { to-month basis }\end{array}$ \\
\hline $\begin{array}{l}\quad \text { Sale of bus } \\
\text { entity through } \\
\text { negotiation based } \\
\text { on service contract } \\
\text { specification (form } \\
\text { of privatisation) }\end{array}$ & 1050 & $\begin{array}{l}\text { - Applicable to bus operations } \\
\text { at local and provincial } \\
\text { government levels }\end{array}$ & $\begin{array}{l}\text { - Contracts are } 5 \text { years in } \\
\text { duration } \\
\text { - New contracts to be } 7 \text { years } \\
\text { - Implemented in the City of } \\
\text { Durban (June 2003) and North } \\
\text { West Province (January 2004) }\end{array}$ \\
\hline
\end{tabular}

Source: Compiled by the authors for the purpose of this paper (SABOA and DoT sources) (2006 data) 
Table II: Differences in approach between tendered and negotiated contract systems in South Africa

\begin{tabular}{|c|c|c|}
\hline & Tendered contracts & Negotiated contracts \\
\hline Authority & Authority decides to tender services & $\begin{array}{l}\text { Authority decides to negotiate services } \\
\text { after approval from Minister of Transport }\end{array}$ \\
\hline Public involvement & $\begin{array}{l}\text { None, except to determine route } \\
\text { network inputs }\end{array}$ & $\begin{array}{l}\text { Notice to negotiate contract is published in } \\
\text { the Government Gazette and other written } \\
\text { media }\end{array}$ \\
\hline Operators & $\begin{array}{l}\text { Operators tender against each other } \\
\text { for the service } \\
\text { A } 10 \% \text { right of first refusal for the } \\
\text { incumbent operator }\end{array}$ & $\begin{array}{l}\text { Contract is negotiated with the incumbent } \\
\text { operator but put out to some form of } \\
\text { competitive bidding when services are } \\
\text { privatised by the provincial or municipal } \\
\text { operators. } \\
\text { No right of first refusal for the incumbent } \\
\text { operator where the services are privatised }\end{array}$ \\
\hline Labour & $\begin{array}{l}\text { Not involved in tendering companies } \\
\text { prior to such companies tendering } \\
\text { A 'clean break' in service provision, } \\
\text { even though the same operator } \\
\text { may win the contract. This causes } \\
\text { instability in the labour force }\end{array}$ & $\begin{array}{l}\text { Involved in tender discussions prior to the } \\
\text { finalisation of the contract } \\
\text { Continuous employment with the same } \\
\text { operator, with the same conditions of } \\
\text { employment for those employees offered } \\
\text { employment. The same employer criterion } \\
\text { is not however necessarily the case in } \\
\text { parastatal and municipal operators if their } \\
\text { owners decide to privatise these companies }\end{array}$ \\
\hline $\begin{array}{l}\text { Conditions of } \\
\text { service labour }\end{array}$ & $\begin{array}{l}\text { Negotiated after award of the tender } \\
\text { with representative unions }\end{array}$ & $\begin{array}{l}\text { Representative unions are consulted prior } \\
\text { to the awarding of the negotiated contract }\end{array}$ \\
\hline $\begin{array}{l}\text { Vehicle } \\
\text { specification }\end{array}$ & $\begin{array}{l}\text { Determined in the tender } \\
\text { specification contract }\end{array}$ & $\begin{array}{l}\text { Determined in the tender specification } \\
\text { contract }\end{array}$ \\
\hline $\begin{array}{c}\text { Service } \\
\text { specification }\end{array}$ & $\begin{array}{l}\text { Determined in the tender } \\
\text { specification contract }\end{array}$ & $\begin{array}{l}\text { Determined in the tender specification } \\
\text { contract with the potential for variation as a } \\
\text { result of the negotiation process }\end{array}$ \\
\hline Contract duration & Seven year contracts & Twelve year contracts \\
\hline $\begin{array}{l}\text { Contract } \\
\text { monitoring }\end{array}$ & $\begin{array}{l}\text { Independent monitoring company } \\
\text { appointed by Authority }\end{array}$ & $\begin{array}{l}\text { Independent monitoring company } \\
\text { appointed by Authority }\end{array}$ \\
\hline $\begin{array}{l}\text { Subsequent } \\
\text { rounds of tenders }\end{array}$ & $\begin{array}{l}\text { Tendered service will be tendered } \\
\text { upon expiry }\end{array}$ & $\begin{array}{l}\text { Negotiated contracts once only, thereafter } \\
\text { the services are tendered }\end{array}$ \\
\hline $\begin{array}{c}\text { Tender } \\
\text { documentation }\end{array}$ & $\begin{array}{l}\text { Documentation compiled by a service } \\
\text { provider on behalf of the Authority }\end{array}$ & $\begin{array}{l}\text { Documentation compiled by a service } \\
\text { provider on behalf of the Authority }\end{array}$ \\
\hline
\end{tabular}

Source: Adapted from Walters \& Cloete (2007)

In summary of this section, an outline of the current policy process is provided in the diagram shown in Figure 1.

2 Tendered contracts: Public transport services that operators tender for in the open market, based on a service design

${ }^{3}$ Negotiated contracts: Services that are negotiated with potential operators based on a service design by a transport authority. These could also be gross or net based.

${ }^{4}$ Interim contracts: Contracts concluded with subsidised operators in 1997 as a transitional measure to tendered and negotiated contracts. These contracts were based on the original services offered by the operators at the time, and were intended as a transitional measure to assist operators to ' $g$ et fit' for the tendering system. 


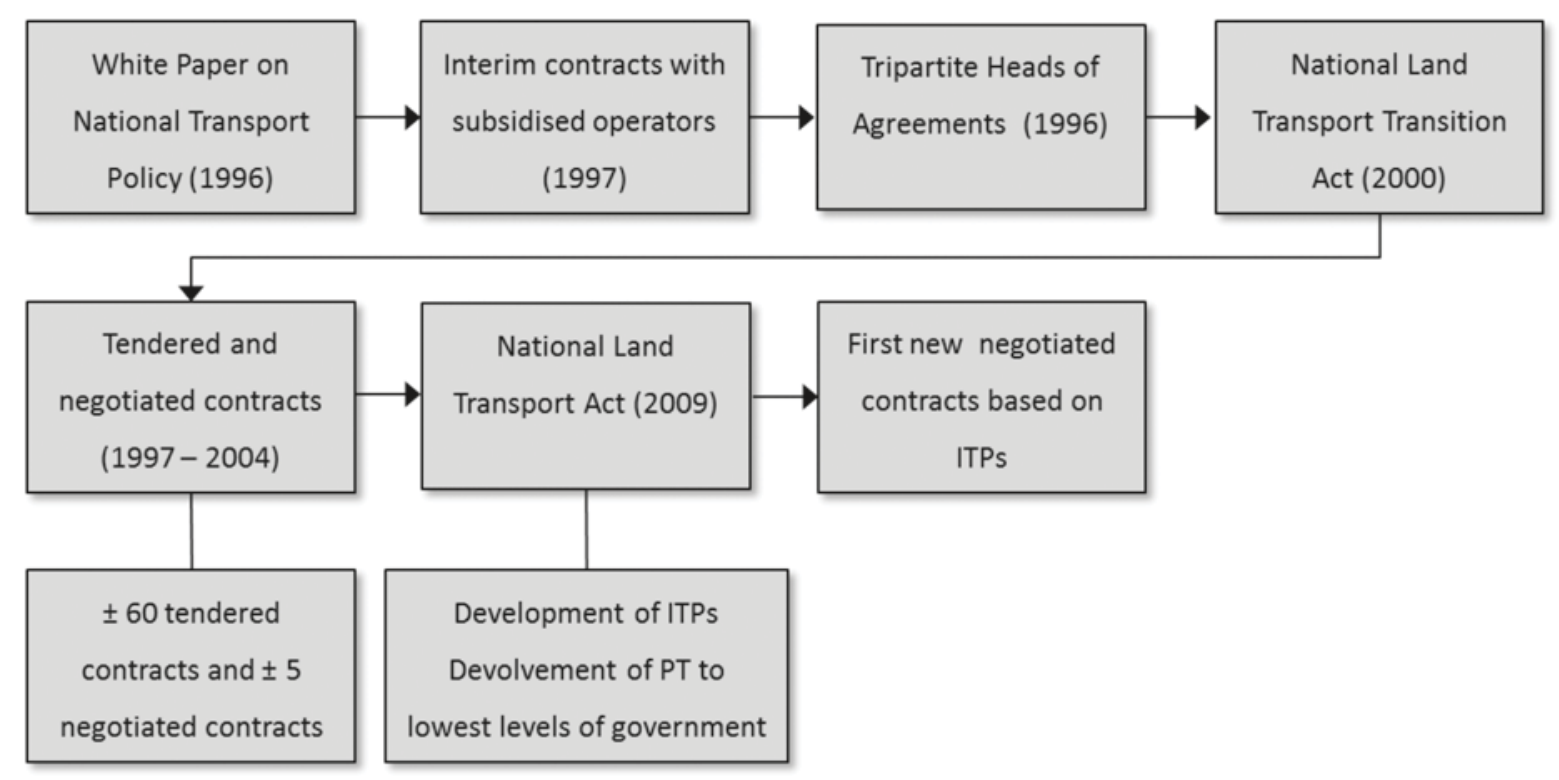

Figure 1: Public transport policy milestones

From the brief summary above it can be seen that the process of competitive tendering has picked up significant opposition and is currently not an option that can be realistically considered. In addition to the HoA issues, there is now a further problem with competitive tenders in that the DoT believes that, based on current South African labour legislation, ${ }^{5}$ all employees of incumbent operators should be transferred, based on the 'going concern' business principle, to the new operator. This view is also supported by organised labour and the Department of Labour (DoL). This poses major issues regarding surplus personnel in right-sized contracts; the disclosure of sensitive remuneration information to a range of bidders so that they can take this into consideration when bidding; the splitting of personnel between various contracts should an existing contract be split into smaller parts; operators facing various labour dispensations within the same operating environment; and the impact on tender efficiency factors and tender costs.

\section{RESEARCH OBJECTIVE}

This paper aims to achieve two objectives: first, to summarise the main findings of a major study into public transport policy in South Africa undertaken in 2009; and secondly, to compare these findings with information gained from an industry survey among subsidised bus operators regarding their views on the slow implementation of the public transport contracting system in South Africa.

\footnotetext{
5 See section 197 of the Labour Relations Act, No 66 of 1995 (as amended) upon which the DoT, DoL and organised labour base their view.
} 


\section{RESEARCH METHODOLOGY}

To achieve the first research objective a summary is provided (only of the public transport policy section of the research project) of a detailed study undertaken in 2009 by Mitchell (2009) following a mixed methods research methodology approach into the effectiveness of South African policy-making, the policy-making process and the contextual forces shaping and influencing policy decisions. In this regard, detailed interviews were conducted with a range of stakeholders in government, academia, consultants and industry. The methodology also involved a questionnaire to council or board members of representative groupings of particular bodies involved in the transport policy facets being analysed. 6

As the Mitchell study only focused on the macro policy objectives, the second objective is to research the opinions of the major subsidised bus operators in South Africa to provide a more detailed overview of the strategic, tactical and operational issues that underpin the slow implementation of the contracting regimen in South Africa. These operators were identified as they are involved in the day-to-day management of bus services and are at the 'coalface' of operating bus services on contract to government. Most, if not all, of these operators have years of experience of public transport contracting and were involved in the initial stage of interim contracts followed by tendered and negotiated contracts. Many are still operating on interim contracts concluded in 1997. A survey response rate of $83 \%$ (15 completed surveys) was achieved. The survey results are representative of the larger contract operators in South Africa representing an estimated 5766 buses (or 83\%) of all contracted buses.

\section{THE MACRO POLICY FINDINGS - THE MITCHELL STUDY}

The Mitchell study (2009) had as its purpose the comparison of the policy-making practices of government over two policy periods, viz. the 1985-1994 period and the post-liberation period, 1994-2006. In his research Mitchell focused on two policy areas, namely commuter bus policy and national roads policy. For the purpose of this paper only the findings relating to the commuter bus policy in the second time period is taken into account as this is also the time period (compared to the 1985-1994 era) during which the most progress has been made (albeit slow) with the implementation of a contracting system for the commuter bus industry.

Mitchell (2009: 267) found that there was general agreement among respondents in the study that on the whole commuter bus transport policy was not adequately implemented in South Africa. The study also found that the main reason for the unsuccessful implementation

\footnotetext{
${ }^{6}$ More details about the research methodology can be found in Chapter 8 of Mitchell's study entitled: A critical analysis of selected aspects of South African Transportation Policy (2009)
} 
was the lack of political will and leadership skills within authorities. Policy implementation had also been attempted through a top-down approach by government through the bureaucracy. Other reasons included the poor follow-through with implementation endeavours, un-coordinated crisis management of transport problems and the lack of consultation with, and readiness to recognise the views of other stakeholders. Mitchell (2009: 267-68) further suggests that the lack of political continuity, leadership, government capacity and bureaucratic sustainability was a large factor in the poor record in respect of public transport policy implementation.

Mitchell also found that there was almost universal agreement '... that particularly for public transport policy, a lack of commitment by implementing agencies had hindered policy implementation as did bureaucratic and institutional jealousies'. Added to this there was 'a lack of realism in the ability to implement the policy during the policy formulation process' (Mitchell, 2009: 268).

Finn and Walters (2010) in their Thredbo 11 Workshop Report on public markets in development identified a number of strategies that are necessary for the implementation of public transport strategies and policy. Some identified were appropriate and capacitated institutional structures, adequate funding, continuity and institutional memory, and that it was important to set realistic goals and expectations and to avoid over-promising transition. The lack of correlation between these findings and that of Mitchell is evident.

Mitchell (2009: 277-78) also found that scope for improvement existed in the following areas of policy analysis and policy-making in South Africa:

- To improve the understanding of the nature of public policy, and of the policy-making process among senior bureaucracy in government and politicians

- To timeously identify transport problems and issues for the transport policy agenda

- To factually analyse all possible policy options and pay sufficient attention to the potential unintended consequences of the various proposals

- To obtain sufficient input from the broader transport society in the policy agenda-setting process in order to take cognisance of the heterogeneity of South African society

- To give adequate attention to government's capacity to implement policy in developing transport policy proposals

- To fully understand the funding implications of especially bus commuter policy before the policy is adopted

- To regularly monitor transport policy implementation.

In defence of the lack of progress with policy implementation, Mitchell states that 'the commuter bus transport policy is more complex, has more variables (than other policies such as national roads - qualification by author of this paper) influencing implementation and has more human and political involvement/interference' (Mitchell, 2009: 324). 
From the above summary of the findings of the Mitchell study it can be concluded that a lack of leadership and political will, capacity to implement the policy, and funding issues were some of the main overriding issues that impacted negatively on the implementation of macro public transport policy in South Africa. These findings, read together with the Finn and Walters (2010) factors that are considered necessary for the implementation of strategies and policies, are corroborated in the survey of subsidised operators in the following section of this paper.

\section{SUBSIDISED BUS OPERATORS SURVEY}

The main findings of the Mitchell study were used to develop a questionnaire that was sent to subsidised operators in the industry to gather their opinions as to why the policy implementation process has been so slow. During June/July 2011, 18 questionnaires were emailed to the largest operators involved in subsidised service contracts (tendered, negotiated and interim contracts). Regular follow-up calls were made to these operators to remind them to complete the questionnaires. Table III represents the split between the various contracting forms and the associated number of buses contracted among the surveyed companies.

Table III: Summary of contract type and number of buses per type of contract

\begin{tabular}{|c|c|c|c|}
\hline Contract type & Number of contracts & Number of buses & $\begin{array}{c}\text { Percentage of bus } \\
\text { fleet under contract }\end{array}$ \\
\hline Interim contract & 25 & 4101 & $71.1 \%$ \\
\hline Tendered contract & 19 & 1174 & $20.4 \%$ \\
\hline Negotiated contract & 10 & 491 & $8.5 \%$ \\
\hline Total & $\mathbf{5 4}$ & $\mathbf{5 7 6 6}$ & $\mathbf{1 0 0 \%}$ \\
\hline
\end{tabular}

Source: Survey results

Note: The number of buses for interim contract operators will not necessarily compare with the figures of Table I as the latter was compiled in 2006. Operators have in the meantime expanded their fleets to meet increasing demand for services

It can be seen that the majority of buses captured in the survey are still operated on interim contracts that were originally concluded in 1997. This is a clear indication of a lack of policy implementation.

\section{DISCUSSION OF RESULTS}

\section{The most important governance issues regarding the implementation of the contracting system}

Stanley and Longva (2010: 81) noted that the Thredbo 11 workshop participants, when considering a successful contracting setting, were of the opinion that in 'judging a 
successful contractual setting were procedural criteria, which refers to various governance arrangements in preparing and implementing the contract and shaping the relationship between purchaser and provider'. To determine which governance issues were believed to be the major stumbling blocks to the implementation of the public transport policy, respondents were required to rate a number of issues on a 5-point Likert-type scale. The response format was anchored not important (1) and very important (5). The combined responses of the respondents were then averaged per issue as portrayed in Figure 2.

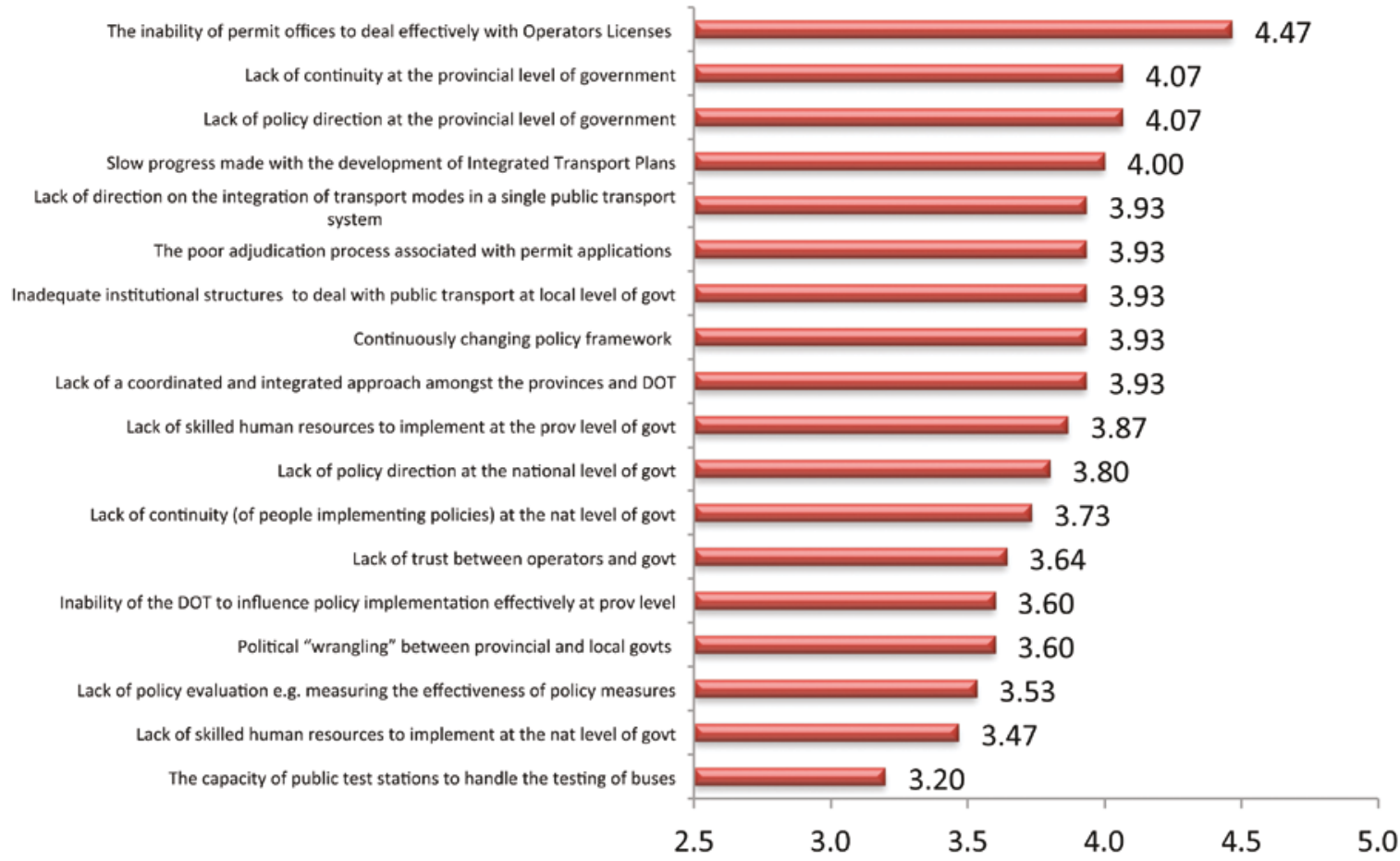

Source: Survey results from 15 subsidised operators

Note: The combined responses of respondents (per issue) were averaged for each issue area

Figure 2: Most important governance issues impacting on the implementation of the public transport contracting system in SA

It can be seen from Figure 2 that the most important governance issues, from an operator's perspective, influencing the implementation of the contracting system are (1) the inability of permit offices to deal effectively with operators' licences (renewal, extension and new licenses) (4.47 average rating); (2) a lack of continuity of personnel to implement provincial transport policies (also often referred to as a lack of institutional memory) (4.07 average rating); (3) a lack of policy direction at the provincial level of government (4.07 average rating); (4) the slow progress made with integrated transport plans - these plans were envisaged in the Land Transport Transition Act of 2000 but to date none have been implemented (4.00 average rating); (5) the lack of direction (guidance) on the integration of the various public transport modes (3.93 average rating); (6) a poor adjudication process in dealing with permit applications (3.93 average rating); (7) inadequate institutional structures to deal with public 
transport at the local (municipality/metro) level of government (3.93 average rating); (8) a continuously changing policy framework (3.93 average rating) and (9) a lack of a coordinated and integrated approach among provinces and the DOT (3.93 average rating).

These issues point to significant policy failure, both at the operational level (permit issues) as well as at the tactical level of implementation at the local/metro and provincial levels of government. The lack of continuity (continuously changing role players) inadequate institutional structures and skills pose a further fundamental problem to the delivery of the policy.

\section{General complexities impacting the implementation of the contracting system}

In the following section the most important general stumbling blocks related to the implementation of the public transport contracting system (tendered and negotiated) are discussed. Figure 3 depicts the respondents' response to the range of statements:

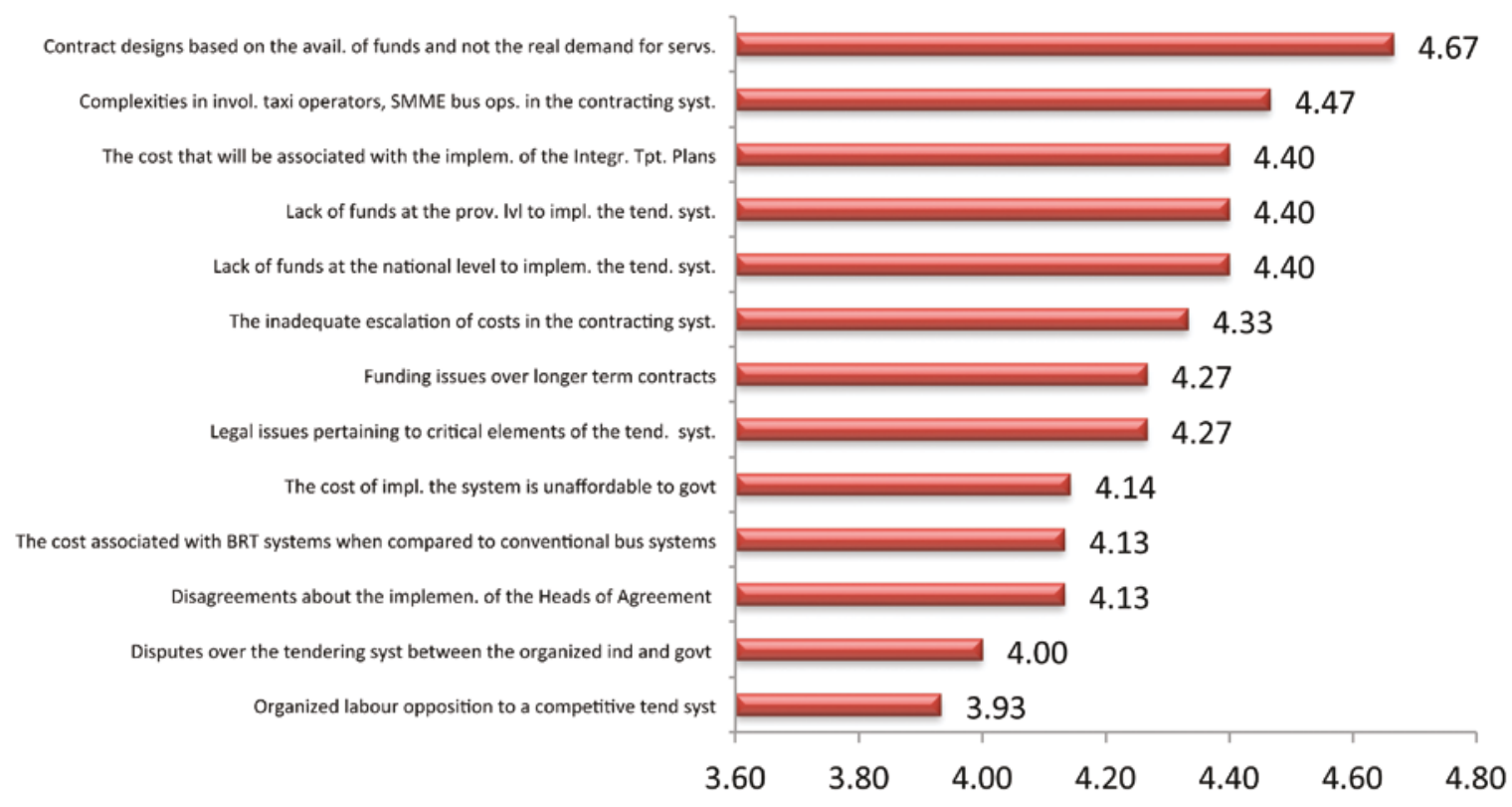

Source: Survey results from 15 subsidised operators

Note: The combined responses of respondents (per issue) were averaged for each issue area

Figure 3: Stumbling blocks related to the implementation of the contracting system

Figure 3 reveals that the funding of services remains the main stumbling block in the implementation of the contracting system (4.67 average rating) together with complexities in involving taxi and small non-subsidised bus operators in the contracting system (4.47 average rating). Finn and Walters (2010: 358) mention, based on Kumurage, Weerawardena and Piyasekera, (2009); Kumurage, Bandara, and Munasinghe (2010); and Schalekamp and Behrens (2010), the complexities of incorporating these operators in formal operations by stating that 'It [informal and small vehicle transit] has usually grown in an organic and 
unregulated manner, and cannot be expected to function in the same manner as corporatised operators'. The complexities of involving small and informal operators in formal contracting regimens in South Africa has been a point of debate for a long time with no solutions evident in the short term.

Other important factors are the cost associated with the implementation of integrated transport plans (also involving unsubsidised operators and services currently operated by subsidised operators but without subsidy); a lack of funds at provincial level to implement a tendering system; and a lack of funds at national level to implement a tendering system (4.40 average rating). Additional issues revolve around the inadequate escalation of costs in the contracting system and funding issues over longer-term contracts (7 and 12 years). It is clear that operators believe that the contracting system's funding issues are overwhelming and a major stumbling block towards the implementation of the contracting system in public transport in the country.

\section{Major issues regarding the implementation of a competitive tendering system}

As mentioned earlier in this paper, the last competitive public transport tenders were awarded in 2002. Since then only a small number of negotiated contracts were concluded. Competitive tendering remains government policy but it is evident that the process had stalled for various reasons, some of which were mentioned earlier on.

Respondents were required to express their views on the major issues related to the further implementation of the tendering system. The responses are included in Figure 4.

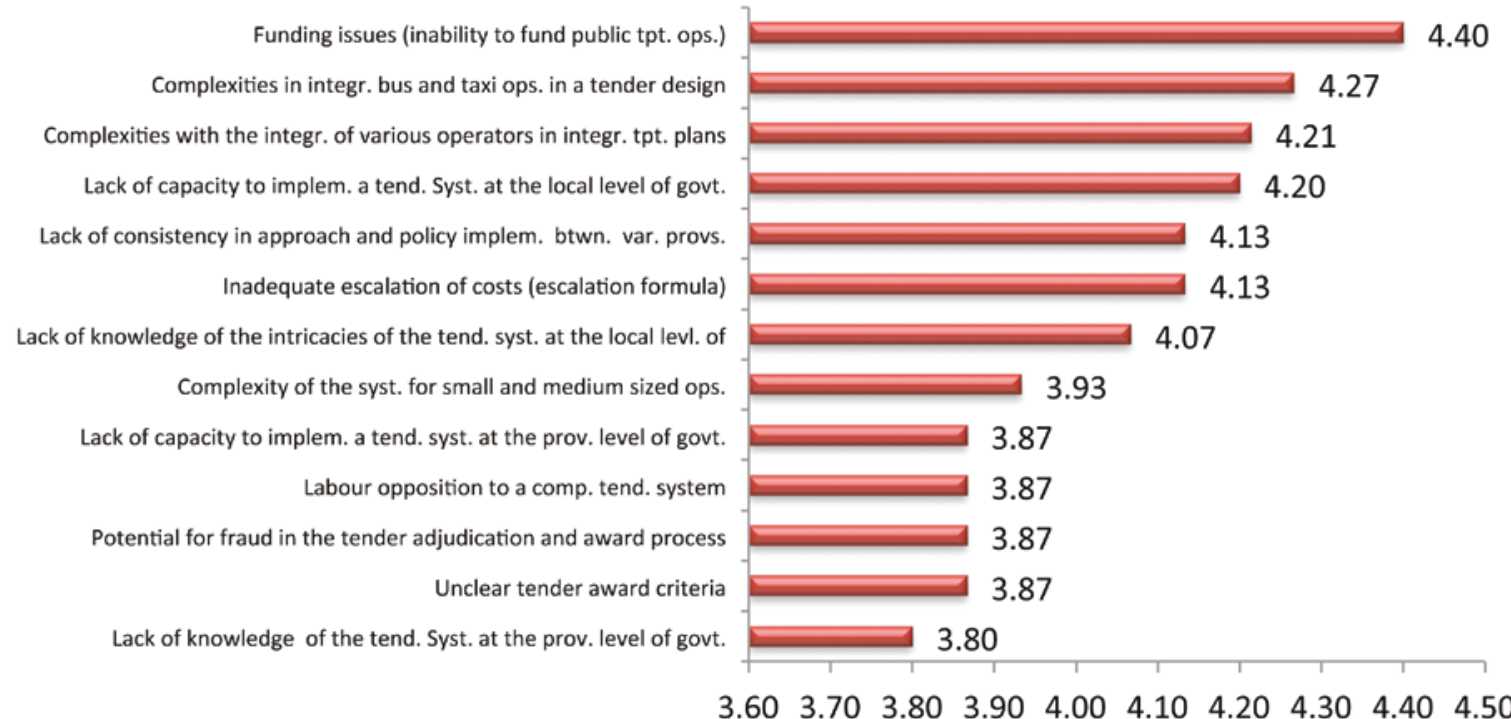

Source: Survey results from 15 subsidised operators

Note: The combined responses of respondents (per issue) were averaged for each issue area

Figure 4: Major issues in the further introduction of a competitive tendering system in South Africa 
As could be expected the funding issues (4.40 average rating) and the complexity of the integration of informal public transport services into a formal tendering system (4.27 and 4.21 average rating respectively) represent the main issues in the further implementation of the tendering system. The lack of human capacity to implement the system (4.20 average rating) together with a lack of consistency of approach between various provincial governments (4.13 average rating) also feature high on the list of issues.

\section{Operators' views on negotiated contracts}

The negotiation of contracts for the rendering of public transport services were first incorporated into the National Land Transport Transition Act of 2000. There were however significant conditions attached and it was really only meant as a transformational tool to assist in black ownership development and growth and to assist previously disadvantaged individuals. In replacement legislation enacted in 2009, the NLTTA was amended to make provision for the negotiation of services in addition to the competitive tendering system. Since the enactment of the National Land Transport Act, the DoT has agreed, as an interim measure, to negotiate all services following the difficulty of convincing labour (among others) of the merits of the competitive tendering system.

The main 'motivator' therefore in South Africa to negotiate contracts appears to be to overcome resistance of organised labour's opposition towards tenders. It is proposed however, that the international evidence of the efficacy of negotiated contracts in public transport also be considered. Hensher and Stanley (2010) report that in the Australian experience, across all jurisdictions that tender and those that negotiate, that there is a tendency for costs to converge and that this underlines the importance of negotiation as an alternative approach.

The survey results indicate that most operators (85.7\%) are in favour of negotiated contracts where the authority carries the revenue risk and $57.1 \%$ where the operator carries the revenue risk. Only 33.3\% of operators are in favour of the current form of net cost tendering where the operator carries the revenue risk. Figure 5 depicts the operators' preferences for negotiated contracts.
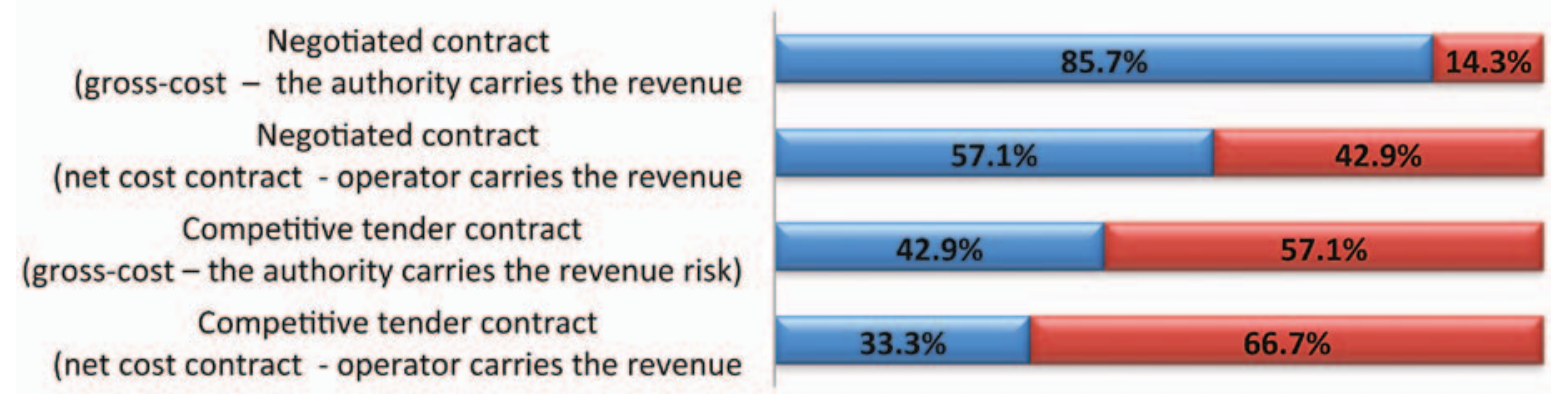

Drefer $\mathbf{n}$ No Prefer

Source: Survey results from 15 subsidised operators

Figure 5: Operators' preference for respective contract types 


\section{Major issues regarding the further implementation of negotiated contracts}

As it is current policy to negotiate the next round of contracts, operators were required to rate a range of issues that would influence the further implementation of negotiated contracts in the country. These issues are depicted in Figure 6.

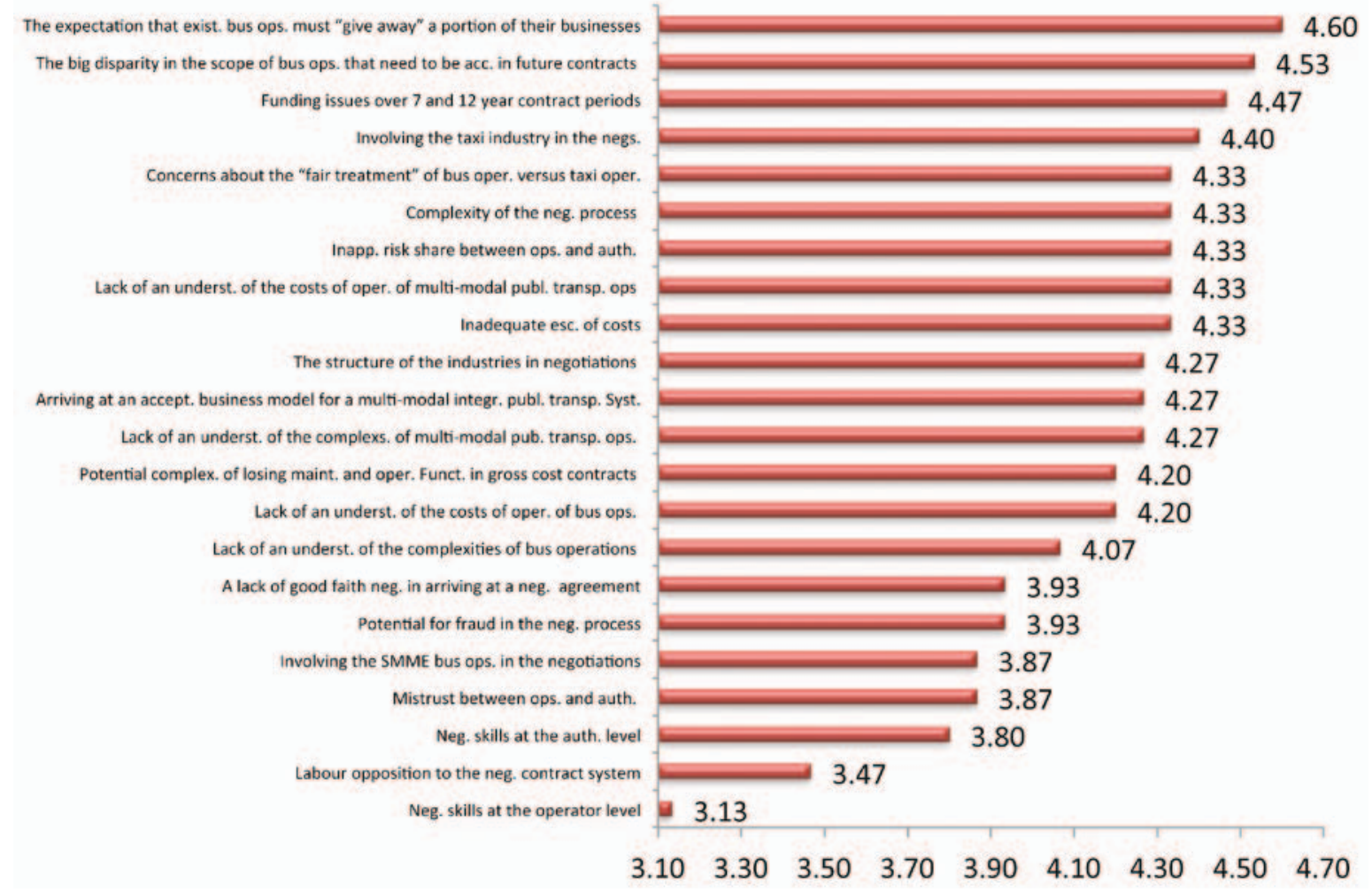

Source: Survey results from 15 subsidised operators

Note: The combined responses of respondents (per issue) were averaged for each issue area

Figure 6: Major issues regarding the further implementation of negotiated contracts

The largest concern that respondents had (4.60 average rating) was that it was generally expected by government during discussions about the tendering system, that operators 'give away' as much as $40 \%$ of their existing businesses to taxi and small bus operators as the current level of funding was inadequate to fund all of the currently unsubsidised services. Once again, the major concern about the funding of the contracting system surfaces in these opinions. Government is under tremendous pressure to include at least the taxi industry in future public transport contracts but cannot afford the financial impact that this may have on the country. Therefore it aims to 'disown' a part of the current subsidised bus services and transfer these services to these operators to satisfy at least a part of that industry's requirement for a subsidy. This approach is not in line with its White Paper objective of growing public transport services as this step only involves the 'sharing' of current bus passengers between the existing bus operators and the taxi industry by forcing the bus industry to 'give up' some of its services to the taxi industry. 
The next major issue was the fact that no bus company has been allowed to add any new routes to its current network since 2002 as a result of a governmental moratorium on the expansion of bus services. In their workshop report Stanley and Longva (2010:82) state that for a successful contractual setting all workshop participants were strongly of the belief that 'in all circumstances (the emphasis of the authors) an operator should be encouraged to grow patronage (e.g. by means such as optimising use of the existing network)'. Sadly, in South Africa, bus operators are not allowed to pursue this objective in their current contracts due to a lack of funds. This is further underlined by the fact that operators operating under interim contracts were, in 2009, forced to change their passenger-based subsidy system to one based on kilometres (South African Government, 2009) so that government could restrain subsidy payments by limiting the kilometres that these buses operate on their respective contracts. Under pressure from communities many operators had to resort to operating unsubsidised services in these instances which place tremendous pressure on their balance sheets. It is expected that these services will have to be included in future contract designs.

Funding issues surfaced again in that $67 \%$ of the respondents gave a very important (5) rating indicating their concerns about the funding of negotiated contracts over seven to 12 year periods (4.47 average rating). The current budget funding cycle of Treasury is based on a three-year planning cycle which is clearly too short to fund longer term contracts. This matter has as yet not been resolved.

The tendency of government to favour the taxi industry also came out as a concern (4.33 average rating) and the difficulty of involving this industry in formal negotiations regarding negotiated contracts (4.40 average rating). Issues such as the complexity of expected negotiations and the negotiation process; an inappropriate risk share between government and operators (relating to inadequate escalation formulae in the respective contracts); and the lack of an understanding of the complexity of multi-modal transport systems were also highlighted by the respondents.

\section{Drivers of the complexity of the current contracting system}

To obtain a general impression of the main complexity drivers of the current contracting system, as depicted in Table I, respondents were required to indicate to which extent they would disagree (1), agree (2) and highly agree (3) with a range of statements regarding issues that were perceived to drive the complexity of the contracting system. Figure 7 shows the perceptions of respondents on the main complexity drivers of the current contracting system. 


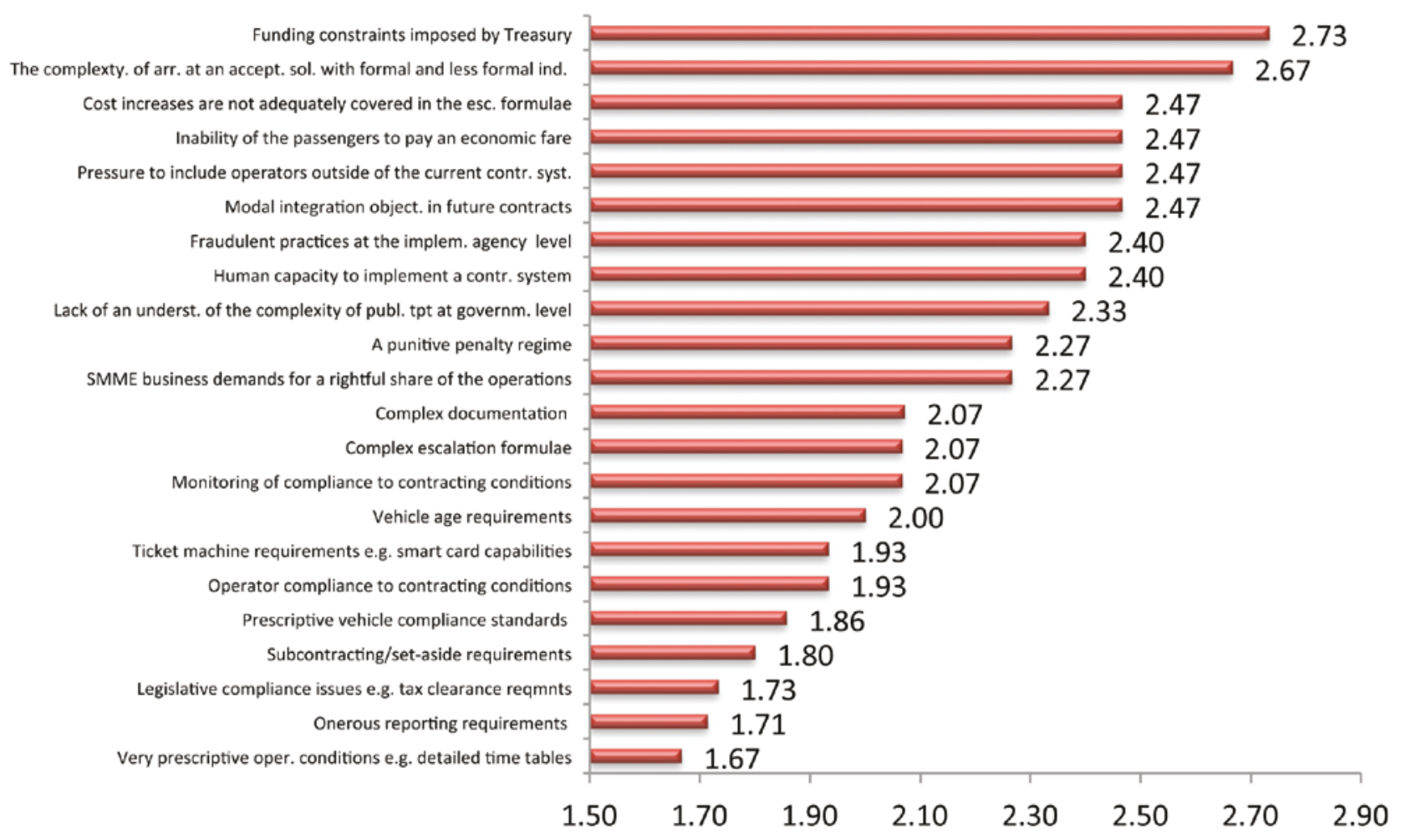

Source: Survey results from 15 subsidised operators

Note: The combined responses of respondents (per issue) were averaged for each issue area

Figure 7: Drivers of the complexity of the current contracting system

The results of Figure 7 indicate that the main concerns revolve around (1) funding (2.73 average rating); (2) the complexity of the negotiation process when involving informal sector operators in the contracting system (2.67 average rating); (3) inadequate escalation formulae in the contracting system (2.47 average rating); (4) the inability of passengers to pay an economic fare (2.47 average rating); (5) pressure to include presently excluded operators into the subsidy system in future (2.47 average rating); (6) modal integration objectives (2.47 average rating); (7) fraudulent practices at the implementation agency level (2.40 average rating) and ( 8 ) human capacity to implement a contracting system (2.40 average rating).

In summary, from the operator survey it can be gleaned that the main stumbling blocks to the implementation of the contracting system in the country can be seen in Table IV. 
Table IV: Summary of the most important issues regarding the implementation of the contracting system (operators' perspective)

\begin{tabular}{|c|c|c|c|c|c|}
\hline Rank & $\begin{array}{c}\text { Governance } \\
\text { issues }\end{array}$ & $\begin{array}{c}\text { Contract system } \\
\text { issues }\end{array}$ & $\begin{array}{c}\text { Competitive } \\
\text { tendering issues }\end{array}$ & $\begin{array}{c}\text { Negotiated } \\
\text { contract issues }\end{array}$ & $\begin{array}{l}\text { Drivers of } \\
\text { complexity }\end{array}$ \\
\hline 1 & $\begin{array}{l}\text { Inability of permit } \\
\text { offices to deal } \\
\text { effectively with } \\
\text { operator licences }\end{array}$ & $\begin{array}{l}\text { Contract designs } \\
\text { based on the } \\
\text { availability of } \\
\text { funds and not the } \\
\text { real demand for } \\
\text { services }\end{array}$ & $\begin{array}{l}\text { Funding issues } \\
\text { (availability } \\
\text { to fund PT } \\
\text { operations) }\end{array}$ & $\begin{array}{l}\text { The expectation } \\
\text { that existing bus } \\
\text { operators must } \\
\text { 'give away' a } \\
\text { portion of their } \\
\text { businesses }\end{array}$ & $\begin{array}{c}\text { Funding } \\
\text { constraints } \\
\text { imposed by } \\
\text { National Treasury }\end{array}$ \\
\hline 2 & $\begin{array}{c}\text { Lack of continuity } \\
\text { at the provincial } \\
\text { level of } \\
\text { government }\end{array}$ & $\begin{array}{l}\text { Complexities } \\
\text { of involving } \\
\text { taxi operators } \\
\text { and SMME bus } \\
\text { operators in } \\
\text { the contracting } \\
\text { system }\end{array}$ & $\begin{array}{l}\text { Complexities } \\
\text { in integrated } \\
\text { bus and taxi } \\
\text { operations in } \\
\text { tender design }\end{array}$ & $\begin{array}{l}\text { The big disparity } \\
\text { in the scope of } \\
\text { bus operations } \\
\text { that need to be } \\
\text { accommodated in } \\
\text { future contracts }\end{array}$ & $\begin{array}{l}\text { The complexity } \\
\text { of arriving at } \\
\text { an acceptable } \\
\text { solution with } \\
\text { formal and less } \\
\text { formal industries }\end{array}$ \\
\hline 3 & $\begin{array}{l}\text { Lack of policy } \\
\text { direction at the } \\
\text { provincial level of } \\
\text { government }\end{array}$ & $\begin{array}{l}\text { The cost } \\
\text { associated } \\
\text { with the } \\
\text { implementation } \\
\text { of the ITPs }\end{array}$ & $\begin{array}{c}\text { Complexities } \\
\text { in integrating } \\
\text { various operators } \\
\text { in ITPs }\end{array}$ & $\begin{array}{l}\text { Funding issues } \\
\text { over } 7 \text { and } 12 \\
\text { year contracts }\end{array}$ & $\begin{array}{l}\text { Cost increases } \\
\text { not adequately } \\
\text { covered in } \\
\text { the respective } \\
\text { escalation } \\
\text { formulae }\end{array}$ \\
\hline 4 & $\begin{array}{l}\text { Slow progress } \\
\text { made with } \\
\text { integrated } \\
\text { transport plans }\end{array}$ & $\begin{array}{l}\text { Lack of funds at } \\
\text { provincial level } \\
\text { to implement } \\
\text { the tendering/ } \\
\text { contracting } \\
\text { system }\end{array}$ & $\begin{array}{l}\text { Lack of capacity } \\
\text { to implement a } \\
\text { tendering system } \\
\text { at the local level } \\
\text { of government }\end{array}$ & $\begin{array}{l}\text { Involving the } \\
\text { taxi industry in } \\
\text { negotiations for } \\
\text { future contracts }\end{array}$ & $\begin{array}{l}\text { The inability of } \\
\text { passengers to pay } \\
\text { an economic fare }\end{array}$ \\
\hline 5 & $\begin{array}{c}\text { Lack of direction } \\
\text { on the integration } \\
\text { of transport } \\
\text { modes in a single } \\
\text { public transport } \\
\text { system }\end{array}$ & $\begin{array}{l}\text { Lack of funds at } \\
\text { national level } \\
\text { to implement } \\
\text { the tendering/ } \\
\text { contracting } \\
\text { system }\end{array}$ & $\begin{array}{c}\text { Lack of } \\
\text { consistency } \\
\text { in approach } \\
\text { and policy } \\
\text { implementation } \\
\text { between various } \\
\text { provinces }\end{array}$ & $\begin{array}{l}\text { Concerns about } \\
\text { the fair treatment } \\
\text { of bus operators } \\
\text { versus taxi } \\
\text { operators }\end{array}$ & $\begin{array}{c}\text { Pressure to } \\
\text { include operators } \\
\text { outside of } \\
\text { the current } \\
\text { contracting } \\
\text { system }\end{array}$ \\
\hline
\end{tabular}

Source: Survey results from 15 subsidised operators

\section{SUMMARY AND CONCLUSIONS}

The findings of Mitchell (2009) and the results of the survey among the 15 subsidised operators reveal a high level of similarity. The current public transport policy is not being implemented for a variety of reasons, the most notable ones being:

- lack of funding to fund the policy implementation

- lack of capacity to implement the chosen policy

- major operational issues in the permit offices

- lack of policy direction at provincial levels of government

- complexities regarding the integration of the informal taxi services into a formal subsidised industry 
- the lack of progress made with the development and implementation of integrated transport plans.

So what are the solutions? The funding of public transport is a political decision that can only be resolved at that level. Without adequate funding public transport cannot be improved, plans cannot be implemented and human capacity cannot be built. It is also important to be truthful as to what can be realistically expected by way of policy objectives. Maybe the envisaged public transport plans are too ambitious for South Africa in its current developmental state.

How can one expect all these structures to respond adequately to the policy imperatives? One potential solution would be to create more capacity at provincial and national DoT levels to assist these structures to develop such plans but then the capacity to implement and monitor such plans also need to be enhanced at these levels. At the metro levels it will assist greatly if properly structured and capacitated formal transport authorities could be established that will have the necessary capacity to plan, implement and monitor integrated transport plans. The current over-reliance on consultants to develop these plans does not provide long-term stability and capacity. For instance when the consultants withdraw, momentum is lost and plans are not implemented. Such authorities need to have skills such as in engineering, transport planning, urban planning, transport economics, financial management, contract design and management, operational experience, social development, environmental management and marketing. Such dedicated structures could provide the long-term stability that public transport needs in the country and provide the necessary stimulus to implement the policy goals. The long-term funding of these plans need to be addressed, however. It is also important that clarity be obtained about the role that the respective modes of transport need to play in future. The current policy statements are too ambiguous and not well thought through and so cause uncertainty and distrust. 


\section{REFERENCES}

Department of Transport, South Africa. 1996. White Paper on National Transport Policy.

Department of Transport, South Africa. 2007a. Public Transport Strategy.

Department of Transport, South Africa. 2007b. Public Transport Action Plan

Phase 1 (2007-2010): Catalytic Integrated Rapid Public Transport Network Projects.

Department of Transport, South Africa. 2009. National Land Transport Act (Act no 5 of 2009).

Finn, B. \& Walters, J. 2010. Workshop report - Public transport markets in development. Research in Transportation Economics. 29: 354-61.

Hensher, D.A. \& Stanley, J.S. 2010. Contracting regimes for bus services: What have we learnt after 20 years? Research in Transportation Economics. 29: 140-44.

Kumurage, S., Bandara, M. \& Munasinghe, D. 2010. Analysis of economic and social parameters of the three-wheeler taxi service in Sri Lanka. Research in Transportation Economics. 29: 395-400.

Kumurage, S., Weerawardena, J. \& Piyasekera, R. 2009. A concession model to promote rural bus services in Sri Lanka. Paper read at the Thredbo 11 Conference. Delft. Netherlands.

Mitchell, A.F. 2009. A critical analysis of selected aspects of South African Transportation Policy. Doctoral thesis. Johannesburg. University of Johannesburg.

Schalekamp, H. \& Behrens, R. 2010. Engaging paratransit on public transport reform initiatives in South Africa: A critique of policy and an investigation of appropriate engagement approaches. Research in Transportation Economics. 29: 371-378.

South African Government. 2009. Government Gazette No 32142. Public Transport Operations Grant Framework. 17 April 2009.

Stanley, J.S. \& Longva, F. 2010. Workshop report - A successful contractual setting. Research in Transportation Economics. 29: 80-88.

Walters, J. \& Cloete, J.J. 2001. An appraisal of the tender for contract system in the commuter bus industry in South Africa. Chapter 16 in Competition and Ownership in Land Passenger Transport: Selected papers from the 8th International Conference (Thredbo 8), Rio de Janeiro, September 2003 Edited by Hensher, D.A. New York: Elsevier Science. 
Walters, J. \& Cloete, J.J. 2007. The South African experience with negotiated versus competitively tendered bus contracts. Conference proceedings of the 10th THREDBO conference held in Hamilton Island, Australia, August 2007. Conducted by ITLS (Australia). Sydney: ITLS (Australia) University of Sydney.

\section{Table of acronyms}

\begin{tabular}{|l|l|}
\hline DoL & Department of Labour \\
\hline DoT & Department of Transport \\
\hline HoA & Heads of Agreement \\
\hline ITPs & Integrated Transport Plans \\
\hline NLTTA & National Land Transport Transition Act of 2000 \\
\hline PT & Public Transport \\
\hline SABOA & Southern African Bus Operators Association \\
\hline
\end{tabular}

